\title{
Analisis Efektivitas Tenaga Kerja di Masa New Normal pada Departemen Finishing Menggunakan Overall Labor Effectiveness (OLE) (PT Iskandar Indah Printing Textile, Surakarta)
}

\author{
Riya Anjani ${ }^{1 *}$, Indah Pratiwi ${ }^{2}$ \\ ${ }^{1}$ Program Studi Teknik Industri, Universitas Muhammadiyah Surakarta, Surakarta, Indonesia \\ ${ }^{2}$ Peneliti Pusat Studi Logistik dan Optimasi Industri, Universitas Muhammadiyah Surakarta, Surakarta, Indonesia \\ ("riyaanjani01@gmail.com)
}

\begin{abstract}
Abstrak - Overall Labor Effectiveness (OLE) adalah indikator kinerja kunci yang mengukur utilisasi, kinerja, dan kualitas tenaga kerja beserta dampaknya terhadap produktivitas. Tujuan penelitian ini adalah mengetahui efektivitas tenaga kerja PT Iskandar Indah Printing Textile departemen Finishing di masa new normal. Metode yang digunakan dalam penelitian ini adalah OLE dan five why analysis yang merupakan salah satu dari metode Root Cause Analysis (RCA) untuk mengetahui akar penyebab masalah. Berdasarkan hasil penelitian diperoleh nilai OLE sebesar 54\%, nilai tersebut masuk dalam pencapaian dengan tingkat wajar (fairly typical level) pada standar dunia dan masih terindikasi banyak ruang perbaikan yang harus dilakukan, nilai Availability sebesar 84\%, nilai Performance sebesar $78 \%$, dan nilai Quality sebesar 89\%, dengan penyebab nilai OLE rendah adalah operator tidak mencari jalan alternatif yang lebih dekat menuju perusahaan, tidak ada kontrol sparepart dari maintenance, tidak ada genset di departemen finishing dan kurangnya pelatihan kerja. Berdasarkan akar penyebab masalah tersebut diberikan usulan perbaikan yaitu: pemberian surat keterangan bekerja di sektor esensial, menerapkan continous improvement, pengajuan pengadaan genset dan melakukan pelatihan kerja.
\end{abstract}

Kata kunci: efektivitas tenaga kerja; OLE; RCA

\section{PENDAHULUAN}

PT. Iskandar Indah Printing Textile Surakarta merupakan perusahaan penghasil produk kain grey dan kain batik dengan target produksi sesuai permintaan buyer, perusahaan menggunakan sistem produksi make to order (MTO) yang berorientasi kepada buyer 70\% dan 30\% diproduksi sendiri oleh perusahaan menjadi kain batik. Penelitian ini dilakukan pada departemen finishing. Permasalahan yang menjadi latar belakang dalam penelitian ini adalah waktu kerja yang tersedia belum dimanfaatkan secara maksimal oleh keryawan, masih banyak jam kerja yang belum dioptimalkan secara maksimal. Oleh karena itu perlu dilakukan pengukuran terhadap tingkat efektivitas tenaga kerja sehingga perusahaan dapat memaksimalkan potensi dan performa karyawan. Metode yang digunakan adalah Overall Labor Effectiveness (OLE) menurut (Devani \& Syafruddin, 2018) OLE adalah indikator kinerja kunci yang mengukur utilisasi, kinerja, dan kualitas tenaga kerja beserta dampaknya terhadap produktivitas. Faktor yang diukur OLE yaitu ketersediaan (availability) yaitu persentase waktu yang dihabiskan pekerja, kinerja (performance) yaitu jumlah produk yang diserahkan serta kualitas (quality) yaitu persentase produk tanpa cacat (Yani, 2015). Kemudian dilakukan analisa untuk perbaikan menggunakan metode Five-Why yang merupakan salah satu dari metode Root Cause Analysis (RCA) untuk mengidentifikasi akar penyebab masalah sehingga didapatkan solusi perbaikan terbaik (Wibowo, 2018).

\section{STUDI LITERATUR}

Penelitian ini mengambil sumber dari jurnal-jurnal segala referensi guna mendukung kebutuhan peneliti, sumber yang diambil adalah sumber yang berkaitan dengan pengaruh efektivitas di sebuah perusahaan, analisis dampak dari penerapan new normal, dan penyelesaian akar penyebab permasalahan atau root cause analysis. Sumber lain juga diambil dari beberapa penelitian Tugas Akhir mahasiswa khususnya Jurusan Teknik Industri. 


\section{METODOLOGI}

Penelitian ini dilakukan di PT. Iskandar Indah Printing Textile Surakarta pada departemen finishing yang memiliki tugas yaitu inspecting, folding dan QC kain grey, dimana selama penerapan new normal departemen finishing mengalami penurunan performa karena banyak waktu kerja yang belum dimanfaatkan dengan optimal, salah satunya yaitu menumpuknya kain grey pada proses inspecting, sehingga jika kain belum melalui proses pemeriksaan maka kain belum bisa dilanjutkan untuk tahap selanjutnya. Penelitian ini dilaksanakan pada tanggal 1 Juni-31 Juli 2021. Metode yang digunakan adalah OLE dan Root Cause Analysis, dengan pengumpulan data yaitu observasi lapangan, melakukan pengamatan karyawan pada proses finishing mulai dari pemeriksaan hingga proses pelipatan kain grey serta mengidentifikasi permasalahan yang terjadi dilapangan, wawancara atau brainstorming oleh kepala departemen finishing dan karyawan untuk mengetahui uraian kesesuaian proses, studi literatur berkaitan dengan tema yang diambil guna mendukung jalannya penelitian dan pengambilan data primer secara langsung yaitu data hasil produksi kain grey bulan Juni-Juli 2021, data defect produksi kain grey, data downtime dan data absensi karyawan pada departemen finishing.

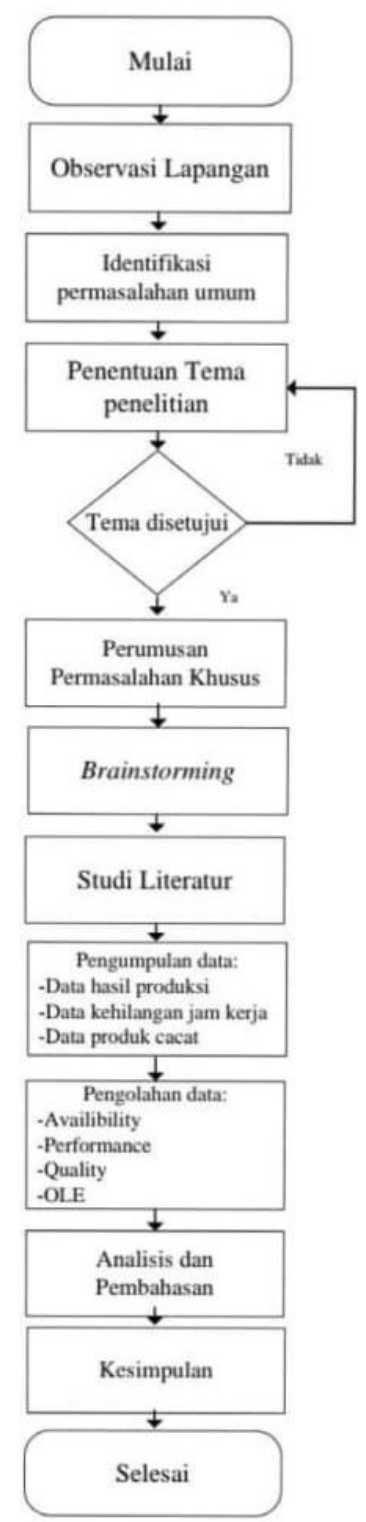

Gambar 1. Flowchart Penelitian 


\section{HASIL DAN DISKUSI}

\section{A. Analisis Overall Labor Effectiveness (OLE)}

\section{1) Perhitungan Availability}

Availability (Ketersediaan) adalah persentase waktu kerja yang dihabiskan pekerja dalam memberikan kontribusi yang efektif pada saat proses produksi, menghitung penggunaan waktu kerja dari waktu yang tersedia untuk kegiatan produksi. Waktu yang diukur dari waktu kerja produktif dibagi dengan waktu yang disediakan oleh perusahaan. Waktu produktif yaitu waktu yang dihabiskan operator dalam melaksanakan kinerjanya tanpa adanya istirahat. Sedangkan jam kerja tersedia adalah jam kerja yang diberikan oleh perusahaan, biasanya dalam SK. Kementrian Ketenagakerjaan waktu yang dianjurkan yaitu $40 \mathrm{Jam} /$ Minggu, sedangkan kehilangan jam kerja seperti karyawan absen, mesin produksi mati. (Yani, 2015). Untuk mengukur availability dengan persamaan 1 berikut.

$$
\text { Availability }=\frac{\text { jam kerja }- \text { kehilangan jam kerja }}{\text { jam kerja yang tersedia }} \times 100 \%
$$

Tabel 1

Data kehilangan jam kerja operator bagian departemen finishing

\begin{tabular}{|c|c|c|c|c|}
\hline Tanggal & $\begin{array}{c}\text { Jam } \\
\text { Kerja } \\
\text { Tersedia } \\
\text { (Menit) }\end{array}$ & $\begin{array}{c}\text { Jam } \\
\text { Kerja } \\
\text { (Menit) }\end{array}$ & $\begin{array}{c}\text { Jam } \\
\text { Kerja } \\
\text { Hilang } \\
\text { (Menit) }\end{array}$ & $\begin{array}{c}\text { Avaibility } \\
(\%)\end{array}$ \\
\hline $01 / 06 / 21$ & 480 & 420 & 5 & 86 \\
\hline $02 / 06 / 21$ & 480 & 420 & 5 & 86 \\
\hline $03 / 06 / 21$ & 480 & 420 & 5 & 86 \\
\hline $04 / 06 / 21$ & 480 & 420 & 5 & 86 \\
\hline $05 / 06 / 21$ & 360 & 360 & 5 & 82 \\
\hline $07 / 06 / 21$ & 480 & 420 & 5 & 86 \\
\hline $08 / 06 / 21$ & 480 & 420 & 20 & 83 \\
\hline $09 / 06 / 21$ & 480 & 420 & 20 & 83 \\
\hline $10 / 06 / 21$ & 480 & 420 & 20 & 83 \\
\hline $11 / 06 / 21$ & 480 & 420 & 20 & 83 \\
\hline $12 / 06 / 21$ & 360 & 360 & 15 & 79 \\
\hline $14 / 06 / 21$ & 480 & 420 & 20 & 83 \\
\hline $15 / 06 / 21$ & 480 & 420 & 10 & 85 \\
\hline $16 / 06 / 21$ & 480 & 420 & 10 & 85 \\
\hline $17 / 06 / 21$ & 480 & 420 & 10 & 85 \\
\hline $18 / 06 / 21$ & 480 & 420 & 20 & 83 \\
\hline $19 / 06 / 21$ & 360 & 360 & 20 & 78 \\
\hline $21 / 06 / 21$ & 480 & 420 & 20 & 83 \\
\hline $22 / 06 / 21$ & 480 & 420 & 20 & 83 \\
\hline $23 / 06 / 21$ & 480 & 420 & 20 & 83 \\
\hline $24 / 06 / 21$ & 480 & 420 & 20 & 83 \\
\hline $25 / 06 / 21$ & 480 & 420 & 20 & 83 \\
\hline $26 / 06 / 21$ & 360 & 360 & 20 & 78 \\
\hline $28 / 06 / 21$ & 480 & 420 & 5 & 86 \\
\hline $29 / 06 / 21$ & 480 & 420 & 5 & 86 \\
\hline $30 / 06 / 21$ & 480 & 420 & 5 & 86 \\
\hline
\end{tabular}

\begin{tabular}{|c|c|c|c|c|}
\hline Tanggal & $\begin{array}{c}\text { Jam } \\
\text { Kerja } \\
\text { Tersedia } \\
\text { (Menit) }\end{array}$ & $\begin{array}{c}\text { Jam } \\
\text { Kerja } \\
\text { (Menit) }\end{array}$ & $\begin{array}{c}\text { Jam } \\
\text { Kerja } \\
\text { Hilang } \\
\text { (Menit) }\end{array}$ & $\begin{array}{c}\text { Avaibility } \\
(\%)\end{array}$ \\
\hline $01 / 07 / 21$ & 480 & 420 & 10 & 85 \\
\hline $02 / 07 / 21$ & 480 & 420 & 15 & 84 \\
\hline $03 / 07 / 21$ & 360 & 360 & 5 & 82 \\
\hline $05 / 07 / 21$ & 480 & 420 & 5 & 86 \\
\hline $06 / 07 / 21$ & 480 & 420 & 5 & 86 \\
\hline $07 / 07 / 21$ & 480 & 420 & 5 & 86 \\
\hline $08 / 07 / 21$ & 480 & 420 & 5 & 86 \\
\hline $09 / 07 / 21$ & 480 & 420 & 5 & 86 \\
\hline $10 / 07 / 21$ & 360 & 360 & 5 & 82 \\
\hline $12 / 07 / 21$ & 480 & 420 & 10 & 85 \\
\hline $13 / 07 / 21$ & 480 & 420 & 10 & 85 \\
\hline $14 / 07 / 21$ & 480 & 420 & 10 & 85 \\
\hline $15 / 07 / 21$ & 480 & 420 & 10 & 85 \\
\hline $16 / 07 / 21$ & 480 & 420 & 10 & 85 \\
\hline $17 / 07 / 21$ & 360 & 360 & 10 & 81 \\
\hline $21 / 07 / 21$ & 480 & 420 & 30 & 81 \\
\hline $22 / 07 / 21$ & 480 & 420 & 30 & 81 \\
\hline $23 / 07 / 21$ & 480 & 420 & 30 & 81 \\
\hline $24 / 07 / 21$ & 360 & 360 & 5 & 82 \\
\hline $26 / 07 / 21$ & 480 & 420 & 5 & 86 \\
\hline $27 / 07 / 21$ & 480 & 420 & 5 & 86 \\
\hline $28 / 07 / 21$ & 480 & 420 & 5 & 86 \\
\hline $29 / 07 / 21$ & 480 & 420 & 0 & 88 \\
\hline $30 / 07 / 21$ & 480 & 420 & 0 & 88 \\
\hline $31 / 07 / 21$ & 360 & 360 & 5 & 82 \\
\hline
\end{tabular}

Berdasarkan tabel 1. data kehilangan jam kerja adalah waktu yang hilang oleh operator dalam satu minggu kerja, diketahui total kehilangan jam kerja sebesar 585 menit dalam periode 1 Juni-31 Juli 2021. Hal ini disebabkan antara lain karena mati listrik, mati mesin, keterlambatan karyawan karena penerapan pemberlakuan pembatasan kegiatan masyarakat (PPKM) di beberapa daerah serta waktu vaksinasi karyawan. Dengan menggunakan data jam kerja tersedia dan data kehilangan jam kerja maka nilai Availability dapat diketahui pada gambar histogram Availability 2 berikut. 


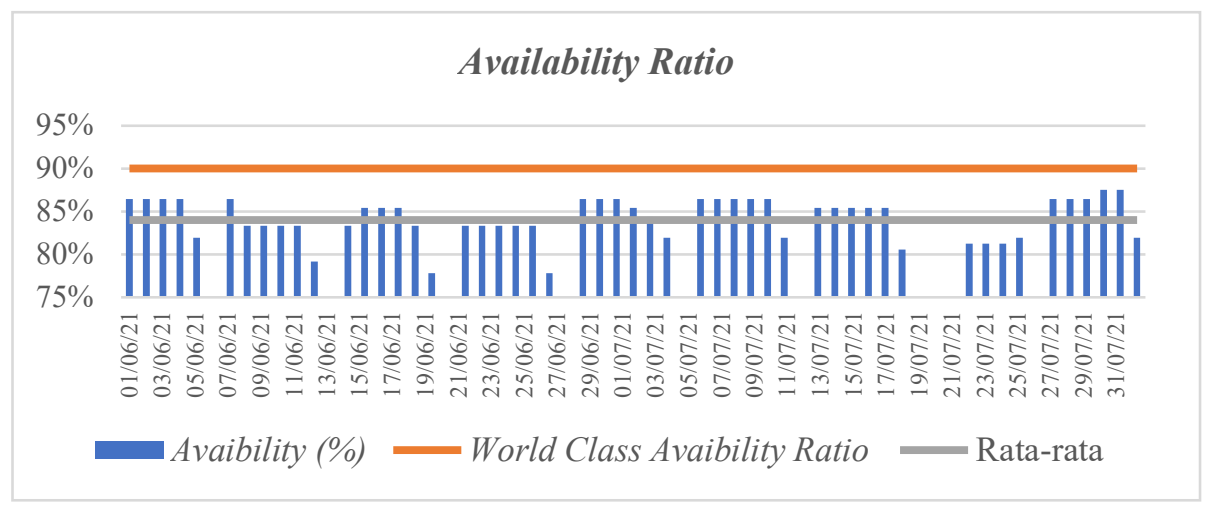

Gambar 2. Histogram Availability Ratio

Gambar 2. diketahui bahwa rata-rata Availability tanggal 1 Juni-31 Juli 2021 sebesar 84\% yang artinya perusahaan hanya mampu mengoptimalkan performance karyawan sebesar $84 \%$ dari potensi yang dimiliki perusahaan, serta hanya sekitar $6 \%$ yang belum dioptimalkan oleh perusahaan, Availability $84 \%$ termasuk sedang, karena masih dibawah world class standar Availability ratio yaitu sebesar $90 \%$ sehingga perusahaan perlu melakukan perbaikan jam kerja yang hilang akibat downtime tersebut agar nilai Availability dapat mengalami peningkatan.

2) Perhitungan Performance

Performance ratio adalah pengukuran kinerja pekerja berdasarkan ouput aktual yang dihasilkan dibagi dengan target yang telah ditetapkan perusahaan.(Pratama, 2018). Perhitungan performance ratio dapat dilakukan dengan menggunakan persamaan 2 berikut.

$$
\text { Performance }=\frac{\text { Actual output }}{\text { Target output }} \times 100 \%
$$

Tabel 2

Data Aktual Produk dan Target Produksi

\begin{tabular}{|c|c|c|c|c|c|c|c|}
\hline Tanggal & $\begin{array}{l}\text { Output } \\
\text { Aktual } \\
\text { (m) }\end{array}$ & $\begin{array}{c}\text { Target } \\
\text { Aktual } \\
(\mathrm{m})\end{array}$ & $\begin{array}{c}\text { Performance } \\
(\%)\end{array}$ & Tanggal & $\begin{array}{l}\text { Output } \\
\text { Aktual } \\
\text { (m) }\end{array}$ & $\begin{array}{c}\text { Target } \\
\text { Aktual } \\
\text { (m) }\end{array}$ & $\begin{array}{c}\text { Performance } \\
(\%)\end{array}$ \\
\hline $01 / 06 / 21$ & 35.51 & 48.00 & 74 & $01 / 07 / 21$ & 36.66 & 48.00 & 76 \\
\hline $02 / 06 / 21$ & 33.97 & 48.00 & 71 & $02 / 07 / 21$ & 36.13 & 48.00 & 75 \\
\hline $03 / 06 / 21$ & 38.82 & 48.00 & 81 & $03 / 07 / 21$ & 45.98 & 48.00 & 96 \\
\hline $04 / 06 / 21$ & 34.90 & 48.00 & 73 & $05 / 07 / 21$ & 29.95 & 48.00 & 62 \\
\hline $05 / 06 / 21$ & 21.54 & 48.00 & 45 & $06 / 07 / 21$ & 35.81 & 48.00 & 75 \\
\hline $07 / 06 / 21$ & 33.53 & 48.00 & 70 & $07 / 07 / 21$ & 32.63 & 48.00 & 68 \\
\hline $08 / 06 / 21$ & 36.06 & 48.00 & 75 & $08 / 07 / 21$ & 33.89 & 48.00 & 71 \\
\hline $09 / 06 / 21$ & 38.90 & 48.00 & 81 & $09 / 07 / 21$ & 36.05 & 48.00 & 75 \\
\hline $10 / 06 / 21$ & 34.00 & 48.00 & 71 & $10 / 07 / 21$ & 22.58 & 48.00 & 47 \\
\hline $11 / 06 / 21$ & 34.04 & 48.00 & 71 & $12 / 07 / 21$ & 34.29 & 48.00 & 71 \\
\hline $12 / 06 / 21$ & 25.04 & 48.00 & 52 & $13 / 07 / 21$ & 35.16 & 48.00 & 73 \\
\hline $14 / 06 / 21$ & 37.56 & 48.00 & 78 & $14 / 07 / 21$ & 36.23 & 48.00 & 75 \\
\hline $15 / 06 / 21$ & 31.51 & 48.00 & 66 & $15 / 07 / 21$ & 36.02 & 48.00 & 75 \\
\hline $16 / 06 / 21$ & 39.37 & 48.00 & 82 & $16 / 07 / 21$ & 34.60 & 48.00 & 72 \\
\hline $17 / 06 / 21$ & 36.65 & 48.00 & 76 & $17 / 07 / 21$ & 24.27 & 48.00 & 51 \\
\hline $18 / 06 / 21$ & 39.13 & 48.00 & 82 & $21 / 07 / 21$ & 27.90 & 48.00 & 58 \\
\hline $19 / 06 / 21$ & 24.49 & 48.00 & 51 & $22 / 07 / 21$ & 33.39 & 48.00 & 70 \\
\hline $21 / 06 / 21$ & 37.27 & 48.00 & 78 & $23 / 07 / 21$ & 37.14 & 48.00 & 77 \\
\hline $22 / 06 / 21$ & 40.02 & 48.00 & 83 & $24 / 07 / 21$ & 26.44 & 48.00 & 55 \\
\hline $23 / 06 / 21$ & 40.02 & 48.00 & 83 & $26 / 07 / 21$ & 36.95 & 48.00 & 77 \\
\hline $24 / 06 / 21$ & 41.78 & 48.00 & 87 & $27 / 07 / 21$ & 39.55 & 48.00 & 82 \\
\hline $25 / 06 / 21$ & 39.70 & 48.00 & 83 & $28 / 07 / 21$ & 38.61 & 48.00 & 80 \\
\hline $26 / 06 / 21$ & 24.04 & 48.00 & 50 & $29 / 07 / 21$ & 36.49 & 48.00 & 76 \\
\hline $28 / 06 / 21$ & 35.00 & 48.00 & 73 & $30 / 07 / 21$ & 34.39 & 48.00 & 72 \\
\hline $29 / 06 / 21$ & 3657 & 48.00 & 76 & $31 / 07 / 21$ & 26.62 & 48.00 & 55 \\
\hline $30 / 06 / 21$ & 37.58 & 48.00 & 78 & & & & \\
\hline
\end{tabular}


Berdasarkan tabel 2. diketahui total hasil output aktual produksi sebesar 1.754 .952 meter, yang mana itu sudah tidak ada produk defect. Sedangkan target aktual yang ditetapkan perusahaan sebesar 2.448 .000 meter, terdapat selisih sebesar 693.04 meter dengan menggunakan data hasil produksi dan target maka nilai performance dapat diketahui pada gambar histogram performance 3 . berikut.

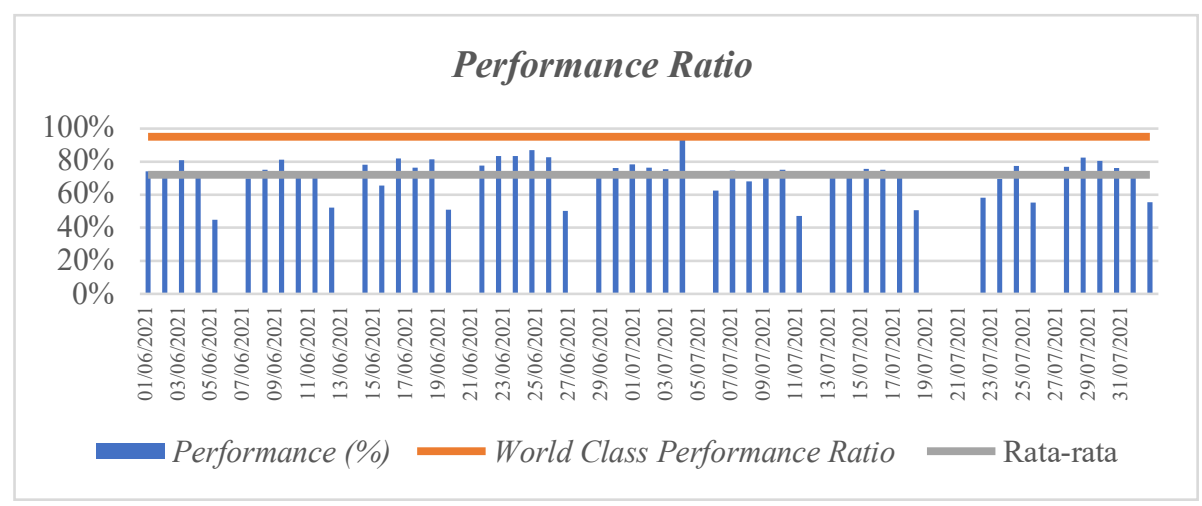

Gambar 3. Histogram Performance Ratio

Gambar 3. menunjukkan histogram performance, diketahui bahwa rata-rata performance tanggal 1 Juni31 Juli 2021 sebesar 78\% yang artinya perusahaan hanya mampu mengoptimalkan performance karyawan sebesar $78 \%$ dari potensi yang dimiliki perusahaan, serta hanya sekitar $17 \%$ yang belum dioptimalkan oleh perusahaan, performace $78 \%$ termasuk sedang karena masih di bawah world class standar performance ratio yaitu sebesar 95\% sehingga perusahaan perlu melakukan perbaikan untuk terus meningkatkan hasil produksinya, sehingga nilai performance dapat mengalami peningkatan.

\section{3) Perhitungan Quality}

Quality ratio adalah pengukuran kemampuan pekerja dalam menghasilkan produk tanpa cacat atau sesuai dengan standar kualitas yang telah perusahaan tetapkan, fokusnya terdapat pada kerugian dari banyaknya kerusakan yang terjadi pada produk (Anwardi, 2018). Perhitungan quality ratio dapat dilakukan dengan menggunakan persamaan 3 berikut.

$$
\text { Quality }=\frac{\text { Hasil Produksi-Produk Cacat }}{\text { Hasil Produksi }} \times 100 \%
$$


Tabel 3

Data Hasil Produksi dan Produk Cacat

\begin{tabular}{cccc}
\hline Tanggal & $\begin{array}{c}\text { Output } \\
\text { Aktual } \\
(\mathrm{m})\end{array}$ & $\begin{array}{c}\text { Produk } \\
\text { Defect } \\
(\mathrm{m})\end{array}$ & $\begin{array}{c}\text { Quality } \\
(\%)\end{array}$ \\
\hline $01 / 06 / 21$ & 35.51 & 3.718 & 90 \\
$02 / 06 / 21$ & 33.97 & 4.103 & 88 \\
$03 / 06 / 21$ & 38.82 & 4.405 & 89 \\
$04 / 06 / 21$ & 34.90 & 4.220 & 88 \\
$05 / 06 / 21$ & 21.54 & 4.420 & 79 \\
$07 / 06 / 21$ & 33.53 & 4.320 & 87 \\
$08 / 06 / 21$ & 36.06 & 5.453 & 85 \\
$09 / 06 / 21$ & 38.90 & 4.781 & 88 \\
$10 / 06 / 21$ & 34.00 & 4.696 & 86 \\
$11 / 06 / 21$ & 34.04 & 5.106 & 85 \\
$12 / 06 / 21$ & 25.04 & 4.191 & 83 \\
$14 / 06 / 21$ & 37.56 & 5.479 & 85 \\
$15 / 06 / 21$ & 31.51 & 4.751 & 85 \\
$16 / 06 / 21$ & 39.37 & 4.389 & 89 \\
$17 / 06 / 21$ & 36.65 & 5.051 & 86 \\
$18 / 06 / 21$ & 39.13 & 3.951 & 90 \\
$19 / 06 / 21$ & 24.49 & 3.555 & 85 \\
$21 / 06 / 21$ & 37.27 & 3.742 & 90 \\
$22 / 06 / 21$ & 40.02 & 4.975 & 88 \\
$23 / 06 / 21$ & 40.02 & 3.743 & 91 \\
$24 / 06 / 21$ & 41.78 & 5.211 & 88 \\
$25 / 06 / 21$ & 39.70 & 3.919 & 90 \\
$26 / 06 / 21$ & 24.04 & 3.926 & 84 \\
$28 / 06 / 21$ & 35.00 & 4.477 & 87 \\
$29 / 06 / 21$ & 3657 & 4.766 & 87 \\
$30 / 06 / 21$ & 37.58 & 4.387 & 88 \\
\hline & & &
\end{tabular}

\begin{tabular}{cccc}
\hline Tanggal & $\begin{array}{c}\text { Output } \\
\text { Aktual } \\
(\mathrm{m})\end{array}$ & $\begin{array}{c}\text { Produk } \\
\text { Defect } \\
(\mathrm{m})\end{array}$ & $\begin{array}{c}\text { Quality } \\
(\%)\end{array}$ \\
\hline $01 / 07 / 21$ & 36.66 & 4.109 & 89 \\
$02 / 07 / 21$ & 36.13 & 2.927 & 92 \\
$03 / 07 / 21$ & 45.98 & 3.472 & 92 \\
$05 / 07 / 21$ & 29.95 & 2.482 & 92 \\
$06 / 07 / 21$ & 35.81 & 4.414 & 88 \\
$07 / 07 / 21$ & 32.63 & 4.373 & 87 \\
$08 / 07 / 21$ & 33.89 & 3.861 & 89 \\
$09 / 07 / 21$ & 36.05 & 2.453 & 93 \\
$10 / 07 / 21$ & 22.58 & 4.104 & 82 \\
$12 / 07 / 21$ & 34.29 & 2.354 & 93 \\
$13 / 07 / 21$ & 35.16 & 2.935 & 92 \\
$14 / 07 / 21$ & 36.23 & 4.129 & 89 \\
$15 / 07 / 21$ & 36.02 & 3.871 & 89 \\
$16 / 07 / 21$ & 34.60 & 2.984 & 91 \\
$17 / 07 / 21$ & 24.27 & 4.473 & 82 \\
$21 / 07 / 21$ & 27.90 & 2.323 & 92 \\
$22 / 07 / 21$ & 33.39 & 4.004 & 88 \\
$23 / 07 / 21$ & 37.14 & 3.051 & 92 \\
$24 / 07 / 21$ & 26.44 & 4.057 & 85 \\
$26 / 07 / 21$ & 36.95 & 4.392 & 88 \\
$27 / 07 / 21$ & 39.55 & 3.323 & 92 \\
$28 / 07 / 21$ & 38.61 & 3.496 & 91 \\
$29 / 07 / 21$ & 36.49 & 2.868 & 92 \\
$30 / 07 / 21$ & 34.39 & 3.035 & 91 \\
$31 / 07 / 21$ & 26.62 & 3.917 & 85 \\
\hline & & & \\
\hline
\end{tabular}

Berdasarkan tabel 3. Produk defect adalah produk cacat dalam proses produksi seperti terkena oli mesin, kotor dan salah pakan mesin tenun. Perhitungan quality pada tabel 3. menunjukkan data produksi dengan produk cacat perusahaan selama periode 1 Juni-31 Juli 2021 dengan rata-rata hasil produksi yaitu sebesar 1.754.952 meter sedangkan produk cacat (defect) sebanyak 203.14 meter. Dengan menggunakan data hasil produksi dan produk cacat dapat diketahui histogram quality ratio pada gambar 4.

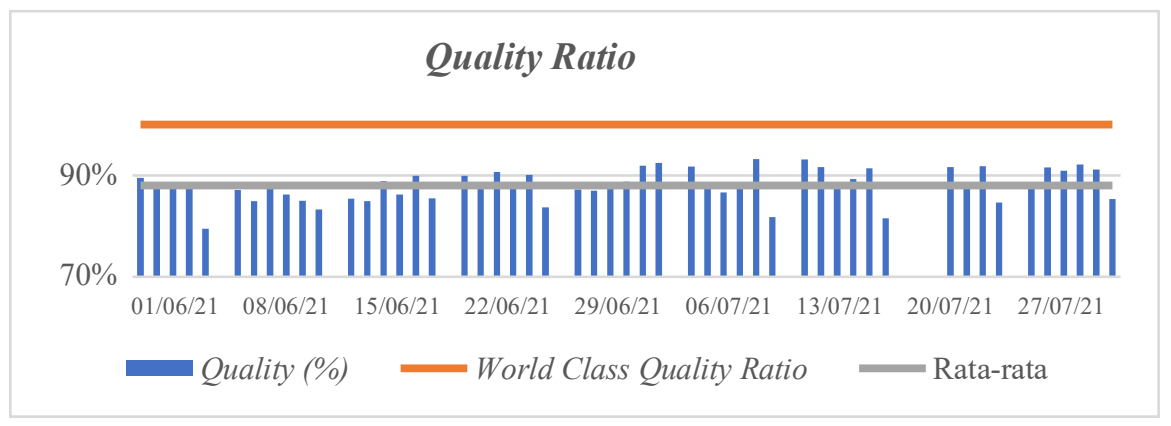

Gambar 4. Histogram Quality Ratio

Gambar 4. menunjukkan histogram quality ratio tanggal 1 Juni-31 Juli 2021, diketahui rata-rata kualitas produksi sebesar $89 \%$ yang berarti presentase produk sempurna atau tanpa produk cacat sebesar $89 \%$. Sehingga hanya terdapat $11 \%$ dari quality yang belum dioptimalkan dari perusahaan untuk memenuhi world class standar quality yaitu sebesar 100\%.

4) Perhitungan OLE

Overall Labor Effectiveness (OLE) adalah indikator kinerja kunci yang mengatur utilitas, kinerja dan kualitas tenaga kerja beserta dampaknya terhadap produktivitas. (Kronos, 2007) Nilai OLE dapat diketahui melalui 3 faktor yakni quality, availibily, dan performance. Nilai OLE diketahui dengan mengalikan availibility, performance, dan quality.(Manik, 2018) Presentase nilai OLE tanggal 1 Juni-31 Juli 2021 pada departemen 
Finishing dapat dilihat pada gambar 5. Histogram OLE.

$$
\text { OLE }=\text { Availability } \times \text { Performance } \times \text { Quality }
$$

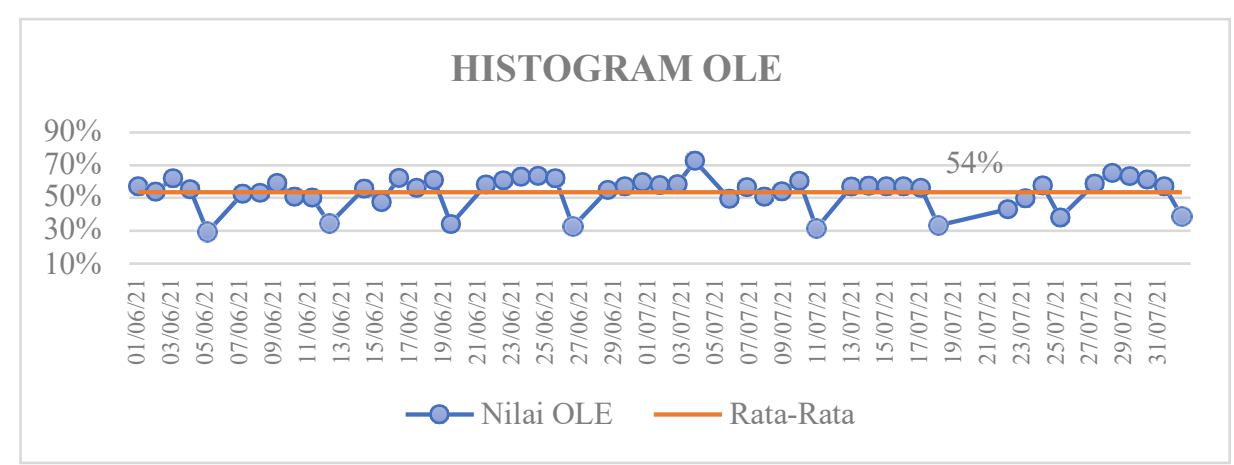

Gambar 5. Histogram OLE

Berdasarkan gambar 5. rata-rata nilai OLE tanggal 1 Juni-31 Juli 2021 sebesar $54 \%$, artinya perusahaan hanya mampu mengkonvensi dari potesi karyawan sebesar 54\% untuk menjadi output yang layak dan menguntungkan. Kinerja OLE sebesar 54\% menunjukkan perusahaan mengalami kerugian dikarenakan banyaknya jam kerja yang hilang, dari ketiga indikator tersebut, nilai rata-rata performance ratio memiliki nilai terendah. Penyebab tidak tercapainya nilai rata-rata tersebut dijabarkan dalam five why.

\section{B. Identifikasi root cause analysisis (RCA)}

Root Cause Analysis (RCA) merupakan suatu metode untuk penyelesaian permasalahan dan mengidentifikasi faktor penyebab dari suatu permasalahan.(Kuswardana, 2017) Five Whys Analysis digunakan dalam Root Cause Analysis dalam rangka penyelesaian masalah (problem solving) kinerja OLE di departemen finishing berada di bawah standar dunia. konsep Five Why Analysis ini dengan terus mengajukan pertanyaan mengapa, membentuk suatu rantai penyebab yang membawa ke arah penyebab utama atau akar masalah. Akar permasalahan dapat diketahui dari jawaban terakhir yang didapatkan pada pertanyaan why yang terakhir (Widyasari et al., 2019).

Tabel 4

Akar Penyebab Rata-Rata OLE 54\%

\begin{tabular}{|c|c|c|c|c|c|}
\hline $\begin{array}{l}\text { Gejala } \\
\text { Masalah }\end{array}$ & Why & Why & Why & Why & Why \\
\hline \multirow{5}{*}{$\begin{array}{c}\text { Nilai OLE } \\
54 \% \\
\text { di bawah } \\
\text { Standar } \\
\text { Dunia }\end{array}$} & \multirow{3}{*}{$\begin{array}{c}\text { Kehilangan Jam } \\
\text { Kerja Operator }\end{array}$} & $\begin{array}{c}\text { Operator terlambat } \\
\text { memasuki area } \\
\text { kerja }\end{array}$ & Penerapan PPKM & $\begin{array}{l}\text { Penyekatan pada } \\
\text { jalan akses } \\
\text { perusahaan }\end{array}$ & $\begin{array}{l}\text { Tidak diberikannya } \\
\text { surat bukti kerja }\end{array}$ \\
\hline & & \multirow{2}{*}{$\begin{array}{l}\text { Mesin mati } \\
\text { mendadak }\end{array}$} & $\begin{array}{l}\text { Mesin mengalami } \\
\text { kerusakan }\end{array}$ & $\begin{array}{l}\text { Part mesin ada } \\
\text { yang rusak }\end{array}$ & $\begin{array}{c}\text { Mesin sudah tua } \\
\text { dan sparepart susah } \\
\text { dicari }\end{array}$ \\
\hline & & & $\begin{array}{l}\text { Gangguan listrik } \\
\text { pada departemen } \\
\quad \text { finishing }\end{array}$ & Mati listrik & $\begin{array}{l}\text { Tidak ada genset } \\
\text { pada departemen } \\
\quad \text { finishing }\end{array}$ \\
\hline & \multirow{2}{*}{$\begin{array}{l}\text { Produksi tidak } \\
\text { mencapai target }\end{array}$} & \multirow[t]{2}{*}{ Produk cacat } & $\begin{array}{c}\text { Terjadinya salah } \\
\text { setting pada mesin } \\
\text { tenun }\end{array}$ & \multirow{2}{*}{$\begin{array}{l}\text { Operator kurang } \\
\text { terampil }\end{array}$} & \multirow{2}{*}{$\begin{array}{c}\text { Kurangnya } \\
\text { pelatihan kerja }\end{array}$} \\
\hline & & & $\begin{array}{l}\text { Kain terkena oli } \\
\text { mesin dan kotor }\end{array}$ & & \\
\hline
\end{tabular}




\section{KESIMPULAN}

Dari hasil yang diperoleh maka didapatkan rata-rata nilai OLE 1 Juni-31 Juli 2021 sebesar 54\%, nilai tersebut masuk dalam pencapaian dengan tingkat wajar (fairly typical level) pada standar dunia dan masih terindikasi banyak ruang perbaikan yang harus dilakukan, nilai OLE 54\% artinya perusahaan hanya mampu mengkonvensi dari potesinya untuk menjadi output yang layak dan menguntungkan sebesar 54\%, dan perusahaan mengalami kerugian dikarenakan banyaknya jam kerja yang hilang, tidak terpenuhi target yang telah ditetapkan. Karena terdapat sekitar $31 \%$ dari potensi yang dimiliki oleh perusahaan belum dioptimalkan dengan baik dan masih berada dibawah nilai standar dunia 85\%. Berdasarkan Tabel 4. diketahui akar penyebab masalah menggunakan 5-Why penyebab nilai OLE 54\% adalah operator tidak mencari jalan alternatif yang lebih dekat untuk segera sampai ke perusahaan. tidak ada kontrol sparepart dari maintenance, tidak ada genset di departemen finishing, kurangnya pelatihan kerja. Usulan perbaikan dari analisis akar penyebab masalah tersebut adalah pemberian surat keterangan bekerja disektor esensial, menerapkan continous improvement dimana operator juga bisa menangani permasalahan mesin sendiri tanpa menunggu pihak maintenance, mengajukan pengadaan genset pada departemen finishing, melakukan pelatihan kerja minimal 2 kali dalam setahun dan melakukan evaluasi kerja.

\section{DAFTAR PUSTAKA}

Anwardi, A. (2018). Perbaikan Efektivitas Pekerja Menggunakan Overall Labour Effectiveness dan Fault Tree Analysis Studi Kasus: PT. Riau Graindo Dumai. Jurnal Teknik Industri: Jurnal Hasil Penelitian Dan Karya Ilmiah Dalam Bidang Teknik Industri, 4(1).

Devani, V., \& Syafruddin, S. (2018). Usulan Peningkatan Efektivitas Tenaga Kerja Dengan Menggunakan Metode Overall Labor Effectiveness. Jurnal Ilmiah Rekayasa Dan Manajemen Sistem Informasi, 4(2), 150.

Dobrusskin (2016) Anon, Understanding How to Use The 5-Whys for Root Cause Analysis. Dobrusskin, C., (2016). On the identification of contradictions using Cause Effect Chain Analysis.

Kronos. (2007). Overall Labor Effectiveness (OLE): Achieving a Highly Effective Workforce Achieving a Highly Effective Workforce. http://www.workforceinstitute.org/wp-content/uploads/2008/01/oleachieving-highly-effective-workforce.pdf

Kuswardana. (2017). Analisis Penyebab Kecelakaan Kerja Menggunakan Metode RCA (Fishbone Diagram Method And 5 - Why Analysis) di PT . PAL Indonesia. Conference on Safety Engineering and Its Application, 141-146. http://journal.ppns.ac.id/index.php/seminarK3PPNS/article/download/236/194/

Manik, R. F. (2018). Analisis Produktivitas Dengan Metode Overall Equipment Effectiveness (Oee) Dalam Penerapan Total Productive Maintenance (Tpm) Pada Mesin Polymer. Journal of Industrial and Engineering System (JIES), 01(01), 53-64.

Wibowo k, 2018. (2018). Analisa dan Evaluasi: Akar Penyebab dan Biaya Sisa Material Konstruksi Proyek Pembangunan Kantor Kelurahan di Kota Solo, Sekolah, dan Pasar Menggunakan Root Cause Analysis (RCA) dan Fault Tree Analysis (FTA) Kristanto. 59(9-10), 303-310.

Widyasari, D., Setiawan, N. Y., \& Perdanakusuma, A. R. (2019). Evaluasi Dan Perbaikan Proses Bisnis Pengelolaan Siswa Menggunakan Business Process Improvement (Studi Pada: Lingua Institute). Jurnal Pengembangan Teknologi Informasi Dan Ilmu Komputer, 3(6), 6133-6141.

Yani, N. (2015). Usulan Perbaikan Efektivitas Kinerja Pekerja Di Departemen Veneer Dengan Menggunakan Overall Labor Effectiveness (OLE) Dan Root Cause Analysis (Studi Kasus: Pt. Asia Forestama Raya). Majapahit Techno, 5(2), 1-5. 